\title{
Saturnalia Revisited: Gezi Park Protests and Carnival Today
}

\section{Retorno a la Saturnalia: las protestas del parque Gezi y el carnaval hoy}

ABSTRACT: The present article conjoins the history of Taksim district from the $19^{\text {th }}$ century to the early years of the Turkish Republic, up to the events of May $28^{\text {th }}, 2013$, known as Gezi Park protests. In trying to determine whether a shared memory of displacement cuts through such different historical layers of the Republic, the article seeks answers for the provenance of the protests and its deployment on the public and private spheres. The analysis borrows from Bakhtinian carnival and carnivalesque, and posits the question whether a different carnival sense of the world, diverging from that of Bakhtin, is predominantly becoming the rule in national and international movements of dissent.

Keywords: Gezi Park, Taksim, protests, Bakhtin, carnival.

RESUMEN: El presente artículo repasa la historia del distrito Taksim entre el siglo XIX y los primeros años de la república turca, hasta llegar a los eventos del 28 de mayo de 2013, conocidos como las protestas del parque Gezi. El artículo busca respuestas a los orígenes de las protestas, así como su desarrollo tanto en las esferas pública como privada. Para tratar de determinar si existe una memoria de exclusión que informe los diferentes estratos históricos de la república, el análisis utiliza los conceptos de carnaval y lo carnavalesco teorizados por Bajtin e interroga la posibilidad de que otros modelos de carnaval, diferentes de los preconizados por Bajtin, se constituyan en la norma para los diversos movimientos de protesta a nivel nacional e internacional.

Palabras clave: parque Gezi, Taksim, protestas, Bajtin, carnaval. 
Taksim Meydan1, located on the European side of Istanbul, is a buzzing social, cultural, economic and touristic epicenter with its evercrowded main street Istiklal running perpendicular to the circular outline of the square. Where the street merges into the square stands Cumhuriyet Anit1 of 1928. On the south end of the monument, Mustafa Kemal can be seen with his companion in arms İsmet İnönü and Fevzi Çakmak Pashas somewhat slantingly overlooking the main street and dressed in the most up-to-date Western fashion (civil and military) of the time to symbolize the modernization efforts of the nascent Republic. Less prominent and eye-catching, and for that matter more intriguing figures though can be found on the west and east sides, in the roundels; one depicting a late Ottoman woman with a veil covering her sorrowful face, and the other unveiled, an early Republic woman, looking sanguinely at the skies. $^{1}$

Roughly a century and two decades before the erection of the monument, Topçu Kışlası (1806, The Taksim Military Barracks) was built on the site by the command of Sultan Selim III, as a token of his desire to modernize the backward Ottoman army. Not waiting long, the barracks saw service a year later, and were severely damaged during the uprising of Kabakçı Mustafa. Overcoming and recovering from the initial rebellion, the structure enjoyed a relatively peaceful century till it received a decisive blow by yet another uprising in April 19, 1909, after which the military establishment was completely abandoned and left to the whims of fate. Dilapidated, the ghost structure became a habitat for the poor, homeless and the dejected strata of a dying empire. In 1923, it was redesigned, true to the populist spirit of the new Republic, as a makeshift football stadium, and on October the $26^{\text {th }}$ the first national match was played against the national team of Romania ending in a draw of 2-2.

After the death of the founding father Mustafa Kemal, ${ }^{2}$ İsmet İnönü, the second most important man of the state, stepped in and ordered the transference

1. One can speculate on the unusual reversal of directions. That is, in the common wisdom of Kemalist nationalism, the Republican women are generally associated with the West. See Hale Y1lmaz's (2013) book on the significance of dress regulations for women in representing the Western styled, Republican modernity. One could expect the unveiled, early Republic woman figure to be facing west but it is curiously placed on the east side of the monument. As much as the reversal is open to various interpretations, it would be proper to highlight the presence of two Soviet figures (general Mihail Frunze and marshal Kliment Vorosilov) among the attendants standing behind Mustafa Kemal.

2. November 10, 1938. On this day of national mourning, time comes to a halt when the clock strikes 9:05 am. Citizens participate or rather are expected to participate in the one minute moment of silence. 
of the stadium down to its modern place in Beşiktaş (within walking-distance from the square) and renamed it after his surname, BJK (Beşiktaş), İnönü Stadyumu. İnönü's interest in the district and his ambition to carve his name in the modern architectural designs of the country did not stop at that. Henri Prost, a French architect and urban planner hired by the state, offered the draft of a park on the empty space that could be redeveloped by razing the rickety barracks. In 1940, the plan was carried out, and in 1942 it was officially christened İnönü Gezisi. The name, however, has never caught the popular imagination, for the citizens frequenting the park preferred to drop the surname and simply called it Gezi Park1.

Along with such prosperous enterprises at nation building in the mid twentieth century, the state also resorted to other schemes ensuing in sanguinary spectacles. The September 6-7 events (1955) were one of a kind during which a population made of Rums and Armenians then residing in Pera was forced to vacate their homes, workshops, and cemeteries at the threat of rape, looting, and death. What caused the uproar and compelled the ordinary Turkish citizens to gang up on the minorities living around the Taksim-Beyoğlu district occurred on account of a miscalculated move by the government. The house in Thessaloniki, Greece, in which the founding father Mustafa Kemal was born, was alleged to have been attacked by some Greek nationalists. Highly mediatized and dramatized, the report of a bomb detonating in the courtyard was seized by the already stressed government as an instrument of propaganda to tighten its loose grip on the state. The rumour had it, even to the present day, that the bomb was planted there by the National Intelligence Organization (МІт) to create an atmosphere of legitimate and reactionary defensive stance. But the plan backfired as the government did not expect (at least not all of it) the degree of violence the masses would indulge in in their furious and senseless attacks on the minorities. The mosaic, a famous symbol once used to describe the multilingual, multicultural, and multiethnic fabric of Turkish society, was irreversibly cracked. Prospects of mourning over what transpired, or sparing a considerable time on discovering the culprits and questioning the likely causes and consequences of the events, were quickly brushed aside and immediately forgotten as the Grand Champs des Morts of Pera, the famous cemeteries guarding over the non-muslim dead, began to knuckle under the weight of Divan Oteli. ${ }^{3}$ The construction of the Hotel was launched the same year, within a few months from the tumultuous month of September, and was

3. The non-Muslim cemeteries were not the only ones giving way to the modernization efforts of the young Republic. The graveyards of the Muslims were also subjected to the frenzy of 
finished in 1958. Some marble works from the cemeteries, however, have not been completely lost to historical oblivion for they were brought to daylight and still used as stepping stones climbing up to Gezi Park1. ${ }^{4}$

The parochial and unrefined account of Taksim district thus outlined and compacted has surely its shortcomings. It serves though at least one useful end: a personal effort at representation and narrativization of the tremor that the May $28^{\text {th }}$, Tuesday event, alias Gezi Park1 Protests, caused, whose seismic waves can still be felt to this very minute. Hyperbolic as the metaphor might sound, the following nineteen days were indeed tempestuous and catastrophic. With the mainstream media blackened out, or rather busy broadcasting a documentary on penguins, personal reports on the escalating police violence began flooding in and through social media. Taksim district was dead to much of the country for three consecutive days till the police gave in to the growing numbers of protestors on the fourth day and only then the whole event was widely, even obsessively, broadcast. The debris of empty tear gas canisters, dug out pavement stones, broken bottles, burnt rubber and dust could be found scattered around the sight stretching from the park, the hotel, to the monument, the square and Istiklal. No quarter was spared.

Strolling along the barricades built from the remnants of violent clashes, among the tents set up in Gezi Park1, and beside the protestors wearing Guy Fawkes masks, one could not help but think if the whole scene was what Derrida meant by contretemps, time being out of joint.

The world is going badly. It is worn but its wear no longer counts. Old age or youth-one no longer counts in that way. The world has more than one age. We lack the measure of the measure. We no longer realize the wear, we no longer take account of it as of a single age in the progress of history. Neither maturation, nor crisis, nor even agony. Something else. What is happening is happening to age itself, it strikes a blow at the teleological order of history. What is coming, in which the untimely appears, is happening to time but it does not happen in time. Contretemps. The time is out of joint. (Derrida, 2006: 96)

The ancient festival of Saturnalia held each year on the $17^{\text {th }}$ of December was one example of an unhinged time of teleological order during which

construction projects. For a comprehensive diagram on the fate of the graveyards, see Brian Johnson (2005).

4. For a general history of Taksim district and how it is related to the recent Gezi Park1 protests, see the final issue of NTV Tarih magazine. Once a mainstream journal on history, it stopped distribution after its special issue on Gezi Park1, available in Turkish at $<$ www. yasarkenyazilantarih.com>. 
transgressions were allowed and even solicited by the Roman Republic. ${ }^{5}$ Celebrating the seasonal cycle and the triumph of life over death during the winter solstice, when the sun hit the nadir point of its altitude on the horizon, Roman citizens allotted a significant place to the ritualistic meaning of the carnival. The days of Saturnalia were meant not only as religious ceremonials praising the gods overseeing the order of nature; perhaps, more crucially, they were also appropriated as social and political manoeuvres for keeping the delicate balance of social hierarchy. Slaves were allowed to gamble in public, change their cloths of servitude and were even treated as equals with their masters, eating from the same table and entitled to free speech. The week of Saturnalia, allowing such free and complaisant interactions between the slaves and the masters, between the nadir and zenith strata of the Roman Republic, was organized around the cyclical and dialectic nature of death and rebirth. Apropos of the ancient carnivalistic rituals, Bakhtin posits such circular nature as «the very core of the carnival sense of the world», as «the pathos of shifts and changes» of «[...] all-annihilating and all-renewing time» (Bakhtin, 1998: 252).

Thanks to the sacrosanct celebration of opposites, the state was able - or at least it thought it was - to tame and ward off any catastrophe that might befall on the mighty Republic for the rest of the 358 days left in the calendar. Needless to say, Romans strictly prohibited any transgression of the border between the master and the slave after Saturnalia days were over, and any attempt would only result in death. In other words, any act of insubordination would be considered a deliberate public declaration of refusal to comply; a dangerous form of indocilite revealing the fissures on the seemingly smooth surface of the regime.

A single act of successful public insubordination, however, pierces the smooth surface of apparent consent, which itself is a visible reminder of underlying power relations. Because acts of symbolic defiance have such ominous consequences for power relations, the Romans, as Veyne reminds us, dealt more harshly with indocilite than with the mere fractions of law. (Scott, 1990: 205)

5. After the Punic Wars with Carthage, during which Rome faced a threat of total annihilation at the hands of Hannibal Barca, the festival gained an indispensable place within the official lexicon of the Roman Republic. Keeping afresh the memory of utter destruction, it took up a ritualistic value of praising the rebirth of the republic over its imminent demise. 
The Roman Empire is long gone, and the week of Saturnalia is coopted as a marking stone of linear history. Today's carnivalistic acts of defiance, emotive expressions of "shifts and changes», inversions of social order, celebration of life over death might be likened to the ancient precedents of the festival. Over the years, however, the pattern of carnival has also undergone drastic changes for indocilite, a precipitous perforation of official time has become the norm, and the desperate attempt to define one's ontopology within the cone of dislocated time has turned into a national reality. ${ }^{6}$ The paradigm shift is obvious, and a sense of diasporic uncertainty permeates today's carnivals of dissent as Jacques Derrida puts it as regards the notion of national belonging: «All national rootedness, is rooted first of all in the memory or the anxiety of a displaced - or displaceable - population. It is not only time that is "out of joint”, but space in time, spacing» (Derrida, 2006: 103).

The claim thus attributing the same characteristics to the contemporary protest movements popping up around the world for the last decade might sound (or already does) far-fetched and irrelevant. Some recurrent patterns, though, can be found to traverse each one of them, from Occupy Wall Street to Tahrir and Taksim squares. Obviously, such high-profile and popular public spaces have their long and painful histories of displaced populations whose memories have tinged the fervor and the anxiety on re-building or rather safeguarding the nation. Ows, reminiscent of the Great Depression of 1929, has made a call to the $99 \%$, consisting of many (not all) «colors, genders and political persuasions» to unite in the name of stopping «the greed and corruption» of the $1 \%$. Tahrir has more than one layer of revolution in its wake, that's why it has been named the square of liberation. Tahrir is also a unique case of an ongoing displacement, another discarded revolution in progress.

Haunted by the ghosts of September 6-7 events, by the cemeteries lying beneath, by the memory of bloody May $1^{\text {st }}, 1977$, by the assassination of Armenian journalist Hrant Dink in 2007, Taksim is no exception in reminding the dissenters - to repeat Derrida once again - of a threat of looming displacement. Just as the threat of deracination has been one of the main catalysts prompting people to pour on the streets on the $28^{\text {th }}$ of May, 2013, another curious factor, driven by the starkest of contradictions, has helped to maintain the determined posture of the protests. Without any particular political

6. Derrida's definition of the word ontopology in Specters of Marx deserves a quotation at length: «By ontopology we mean an axiomatics linking indissociably the ontological value of present - being [on] to its situation, to the stable and presentable determination of a locality, the topos of territory, native soil, city, body in general» (Derrida, 2006: 103). 
party, agenda, affiliation or fraction standing at the helm, and consisting of diametrically opposed groups, Gezi Park1 protests subsisted on constant negation. Say, a Kemalist, nationalist chant «We are all Mustafa Kemal's soldiers» would be heard at one instant and moments later you could see its denigration on a wall graffiti. Or a popular chant «Shoulder to shoulder against fascism» would be re-phrased by LGBT (standing for Lesbian, Gay, Bisexual and Transgender) as «Leg to shoulder against fascism». One cannot really exhaust the categories of negations and contradictions found in Gezi Park1 Protests. In his foreword to Grundrisse, Martin Nicolaus offers two symbiotic processes in order to grasp a society in motion. The first, in which everything seems dipped in the "marketplace», «circulation of capital» calmness passes itself off as the consonant identity of the whole, whereas the other process, lurking right beneath the former, is characterized by a raging contradiction. The non-identity of the secondary process «stamps its character upon the other and defines the nature of the whole». In doing so, «behind the "no trespassing" signs, barbed-wire fences, armed patrols and guard dogs, contradiction ceases to be a mere reflection and may be studied at the source» (Nicolaus, 1993: 2932 [emphasis in the original]).

The subsequent section of the article is devoted to an overall (though insufficient) sketch of the recent event's source of contradictions, its co-existing paradoxes of «praise and abuse», «youth and old age», «top and bottom», «face and backside» with their roots firmly attached to the historically charged and anxiety-laden symbols of the Taksim district and national belonging (Bakhtin, 1998: 253).

Perhaps the best place to commence the interpretation of the spasmodic trajectory of Gezi Park1 protests would be the Janus faced women of the Republic Monument. Accentuating the nuance between the two incompatible time periods of the Turkish Republic, the figures represent the betwixt and between condition of the Turkish society, caught at the crossroads of occidental and oriental sociopolitical modalities. Indeed, the protests revolved around such pedestal antagonism, between the modern, liberal view of life, and the conservative stance of the government.

Just imagine a prime minister who is on TV almost 24/7 and who preaches to people to «go and consume alcohol at home», to «have at least three children per couple», to «ban their children from attending rock concerts», to «raise pious and well-behaving children», «to eat this kind of bread and not that». 
Imagine again, he and his colleagues giving orders to ban or censor popular TV soaps and films on moral and religious grounds, interfering with the repertory of public theatres and voicing their plans to stop funding the arts like opera and ballet. (Sözalan, 2013: 146)

The protests, as much as they were instantaneous blazes of pent-up resentments against the state intrusion into the private sphere of life, were also testimonial to the long brewing feeling of insecurity, for the personal line was not the only one the government of the Justice and Development Party deigned to cross. Devising a plan to reshape the visage of Taksim district, the party set out to conjure up one of the ghost structures of the square: The Taksim Military Barracks of Sultan Selim the Third. Announced by the Prime Minister Recep Tayyip Erdoğan himself, the structure was planned to be built true to its original architectural design. ${ }^{7}$ The new barracks building, however, would not serve the military purposes as it did during the late $19^{\text {th }}$ and early $20^{\text {th }}$ centuries, it was rather intended to be used as a hotel and a mall.

On May $27^{\text {th }}$, half an hour to midnight, bulldozers rumbled to demolish Gezi Park1. The first tweet was sent a few minutes later and 20 protestors were able to stop the construction team. Next day, around noon, the demolition was resumed, protected by a small contingent of the police force. Tear gas sprayed, the image of one of the protestors, «the woman in red dress», became one of the leading symbols of the protests. ${ }^{8}$ The following day Erdoğan challenged the protestors by sticking to his plan to build the modern barracks, and even lectured the public on the history of Gezi Park1. Setting the challenge to practice, the tents of the protestors in the park were burned down in a dawn raid around 5 a.m. And that was the crucial breaking point in the Gezi Park1 protests, for the first few tweets began mounting up at an immense rate with the hashtags \#heryertaksim, \#direngezipark1 becoming global trending topics. More and more protestors were drawn to the site of the protests. Other cities in the country also seconded the strife in Taksim and well-attended protests were held in the capital Ankara, İzmir, Adana, Mersin, Eskişehir, Hatay, Tunceli, Konya, and Manisa. The Prime Minister Erdoğan's arbitrary and unyielding attitude, the disproportional, excessive use of police force, the anger at the

7. Gezi Park1 was not the only target of demolition plans for the construction of malls. Emek Sinemas1 (1924), the first cinema saloon of the Turkish Republic, was the first to go. It was bulldozed completely on the twentieth of May, 2013.

8. «The woman in red dress», being a national symbol of the protests, had international repercussions as well. 8 women deputies of the Left Ecology Freedom Party of Italy were dressed in red during the parliamentary discussions on the rights of abortion. 
censorship of the mainstream media, were indeed among the main reasons for such wide-scale occurrence of protests. What literally and figuratively set ablaze the country, however, was the fire itself the state employed against the peaceful demonstrators. The act of burning the tents was shocking for it was not one of the usual procedures expected of a government to curb a demonstration. It was rather an act of «state of exception», to borrow from Agamben, in which the «political system» no longer regulated «the forms of life and juridical rules in a determined space», but included «at its very center a dislocating localization [...] into which every form of life and every rule can be virtually taken» (Agamben, 1998: 175 [emphasis in the original]).

It was such a contingent and fragile status of topos, which could be discarded at any minute by the state, or rather its definition/defense in national discourse, that prodded the dissenters to venture on a violent confrontation with the police. Without any definite political agency leading the way, the threat of dislocating localization brought together the most unlikely figures from different sections of society. In other words, what started off as an environmentalist and so called apolitical demonstration was transformed into a complex and politicizing movement of protest testifying to the incidental nature of national belonging and identification. ${ }^{9}$ Slavoj Zizek's analysis of the consequences of contingency for the recent global insurgencies might prove to be valid for Gezi Park1 as well: «[...] violence threatens to explode not when there is too much contingency in the social sphere, but when one tries to eliminate this contingency» (Zizek, 2012: 17).

Straining under the increasing pressure of the protests, the government and the Prime Minister had to take in the claims over Gezi Park1. Erdoğan, not completely abandoning the project of building the barracks, even gave a sociocultural twist to his initial remarks by adding that a plan of a city museum might be included in the original construction drafts, hoping all along to decrease the tension of the protests. There was no going back, however, for the threshold had been crossed and it was no longer a sectoral confrontation between environmentalism and the state oppression, but a collective standout against the threat of national extirpation. The Turkish saying «Once the "djinn" comes out of the bottle, it cannot go back in» would nicely encapsulate the irreversibility of the situation for the genie did not come from Aladdin's magic

9. The debate whether the protestors constituted a depoliticized or politicized bloc dragged on for several days. The ongoing process of politicizing would suit them best, for in the ditch-like comradeship any differences based on political affiliations (though preserved) became null and void. 
lamp granting the master's wishes, but constituted a haunting and mischievous one determined to stay.

If the threat of removal of contingency in the societal constellation, as Zizek put it, were to trigger a chain reaction of violence, it would not be erroneous to claim as well that once such a sensitive element had been touched upon, not only violence but a creative energy of humour might also burst open. At least that was the case with Gezi Park1 protests. Reluctant to lend ear to the nationwide demands of the resistance, Erdoğan, a few hours after losing Taksim square to the protestors, came up with yet another remark on «dispute settlement». Roughly translated, Erdoğan's statements amounted to the following:

Atatürk Kültür Merkezi (Atatürk Cultural Center, toward which the unveiled woman of the monument was turned to) will be demolished and in its place an opera building will be built. We will further initiate the construction of a mosque in the district. I will not ask the permission of a few çapulcu (equivalent of looter in English) for the plans underway.

At 4:00 p.m., the same day, Erdoğan continued on his plethora of aphorisms on a live coverage by one of the pro-government television channels. Cursing the social media apparatus twitter as a societal nuisance, he even went to the extreme of naming everyone an alcoholic regardless of the amount of alcohol consumed. One sip would be enough for stigmatization. Instead of exasperating the so-called looters and without any further breeding of violence, the expression «çapulcu» was immediately transformed into a plaything in the hands of the protestors. Inflected in various Western languages, the word enjoyed international and multilingual renown. Some versions were as follows: English, «to chappul», Spanish, «chapulear», French, «chapouller», Italian, «ciapullare», German, «tschapuliere», etc. ${ }^{10}$ The original denotation of «çapulcu / looter» thus underwent a change in meaning, the new definition of the word designating «someone fighting for her / his rights». Even the famous linguist Noam Chomsky sent his support and solidarity for the Gezi protests through such neologism; and one could see the anglicized usage «I am chappulling everyday» painted on the walls around Taksim district. The metamorphosis of the word is significant at least in two senses. First, as it was mentioned a few pages back, the reappropriation was the perfect example of

10. The inflections may vary due to different interpretations. The English version, though, made it to the Wikipedia. 
negation and adaptation, an act of carnival laughter, if you will, as Bakhtin described it.

Laughter embraces both poles of change, it deals with the very process of change, with crisis itself. Combined in the act of carnival laughter are death and rebirth, negation (a smirk) and affirmation (rejoicing laughter). This is a profoundly universal laughter, a laughter that contains a whole outlook on the world. Such is the specific quality of ambivalent carnival laughter. (Bakhtin, 1998: 254 [emphasis in the original])

And secondly, the neologism stood for the total anonymity of the protestors, for the word did not suggest any specific left or right wing solidarity, or class inclination, but functioned as the overall «outlook on the world». It was a nascent banner of cultural and national determination in time and space, a different modality of citizenship, as each and every political stratification involved in the protests united under the freshly minted insignia of «çapulcu». Even though it is difficult and objectionable to identify a certain political affiliation as the momentum of Gezi protests, Zizek's analysis becomes relevant at this stage:

Recall Ayn Rand's favorite ideological fantasy (from Atlas Shrugged), that of «creative» capitalists going on strike - does this fantasy not find a perverted realization in many strikes today, which are often strikes of the privileged «salaried bourgeoisie» driven by the fear of losing their privileges (the surplus over the minimal wage)? They are not proletarian protests, but protests against the threat of being reduced to a proletarian status. In other words, who dares to strike today, when having the security of a permanent job is itself becoming a privilege? (Zizek, 2012: 12)

Where Zizek misses the mark by a wide margin, however, is in his indiscriminative attribution of a non-proletariat, "salaried bourgeoisie» character to the global strikes today. Gezi is an exception as much as other global movements of protest for one can only speculate on the dynamics of resistance, but cannot reduce the driving factors to the function of one particular class. Truly, the middle-class influence is apparent in Gezi, but to claim a reactionary stand-off against the threat of being reduced to the proletariat class as the leitmotif of the protests sounds awkward at best. Along with the salaried discontent daring to risk the permanent job opportunities, Gezi also taught to establish not only horizontal and vertical associations, but illegally dangerous ones as well. The «Gazi to Gezi: Turkish Protests Unite Minorities Who Distrust Each Other» article published by The Atlantic 
displayed such ambiguous relation between the white collar workers and the seasoned protestors of the proletariat. ${ }^{11}$

«Gazi is known as a nest for terrorists», says Kartal Yuksel, a Gezi Park protest leader, taking a 3 a.m. break from a drawn-out battle with police on June 12 . «Even the young kids start as terrorists against cops. They burn buses for no reason. They don't need provocation to attack the cops. They don't want to accept the force of the government. It's just a way of life for them. They know how to make Molotov cocktails, how to protect themselves from the gas. Although he mistrusts their motivations, Yuksel says the Gazi demonstrators have proven to be invaluable to the determined, if somewhat clueless, middleclass kids clashing with police in Taksim».

«The Gazi guys are happy because up until now, they've been labeled as radical groups», he says. «Right now, most of them are in Taksim. They've helped us a lot, actually [...] today, I'm grateful for them, because most of the techniques we've used have been taken from them». (Anderson, 2013)

Before flying to Morocco on the third of June, the prime minister affirmed and further stretched the divided situation of the country just like Yuksel did. Erdoğan sliced the population in half, warning of the danger of the other $50 \%$, standing indoors, which he claimed to be barely able to hold in check. Four days later, on his return, he was welcomed by the target percentage of the nation with the slogans, «Stand firm, do not bow. The nation is with you», or with a more partisan and militant one, «Let us go and crush Taksim». Fortunately, there was no sign of civil war on the horizon except for the reports of a few civilians' backing of the police force in stopping the demonstrators. Ali İsmail Korkmaz, aged 19, a university student in Eskişehir, was killed by one such civil-state combined groups. Trying to run away from the uniformed police, Korkmaz was beaten to death in one of the side streets of the city. Although the party vehemently rejected the involvement of pro-government civilians in the incident, security cameras told otherwise. The court trial is still on.

Gezi Park1 was evacuated by force on the $15^{\text {th }}$ of June, and another period of strife and chaos ensued slowly but not surely giving its place to a restless resolution. As of today, October 29, when the nation is celebrating the $90^{\text {th }}$ anniversary of the Republic, the net results of the protests are as follows: 3,584

11. Gazi is a ghetto situated on the European side of Istanbul. Consisting mostly of Kurdish / Turkish Alewites, the neighborhood experienced violent clashes in 1995, leaving 22 dead, many of them shot down by the official / illegal bullets of the government at the time. In other words, Gazi, with its underemployed, already back-beaten population is the perfect example of the proletariat class Zizek portrays as the slums beyond the gated communities in Brazil. 
under arrest, 8,041 wounded and 7 dead. As of today, we are celebrating «the project of a hundred years», the inauguration of under-the-Bosphorus tunnel connecting Europe to Asia Minor.

Towards the end of his article «Carnival and Carnivalesque», Bakhtin laments the loss of the good old and bygone days of carnival of the late $17^{\text {th }}$ century, and he complains of a «deterioration» and «dissipation» for he believes carnival to have lost its «authentic sense of a communal performance on the public square». For Bakhtin, no one participates directly in the carnival act anymore, and the participation is always mediated by an already carnivalized literature incapable of «genre-shaping power» (Bakhtin, 1998: 258). Gezi protests might sustain Bakhtin's complaints to a certain extent, for what happened in Gezi was not only lived, direct performance on the public sphere, but also an extensive use of the already carnivalized literature. The mediation itself was turned on its head as was the case with the neologism «çapulcu» and numerous other examples of negations within and without the groups partaking of the carnival act. From the chants of football fans «Tear gas oley!» and the wall graffiti «The only cure is Drogba», to the classical music concerts held in the shadow of the monument, Gezi was the conjoining point of the popular and so called refined cultural preferences.

Romans believed god Ianus, alias Saturn, to be the original ruler of the Capitoline hill, migrating from the territory of Sabine, land of the gods. The citizens of the Republic regarded him as one of the indigenous fathers of the Roman civilization and they feared him as well for he was a foreigner, an exile without a toponym from times immemorial (Versnel, 1994: 146-150). Ianus was the perfect example of homo sacer in Roman law, placed at «the intersection of a capacity to be killed and yet not sacrificed, outside both human and divine law» (Agamben, 1998: 73). Tautological as it is, and if the claim does not already sound far-fetched, today's carnivals of dissent revolve around such sacred figures that can be killed with impunity. Burning the tents in Gezi was just one episode of dislocating localization, and the murder of Ali İsmail its culminating point in the practice of homo sacer. The paradigm shift seems apparent, today's carnivals, just like their counterparts in ancient Rome, nurture on «the anxiety of a displaced - or displaceable - population», by the time of contretemps, and the topos of homo sacer. 


\section{References}

Agamben, G. (1998): Homo Sacer: Sovereign Power and Bare Life, California, Stanford University Press.

Anderson, S. (2013): «Gazi to Gezi: Turkish Protests Unite Minorities Who Distrust Each Other», The Atlantic, June 13. <http://www.theatlantic. com/international/archive/2013/06/gazi-to-gezi-turkish-protests-uniteminorities-who-distrust-each-other/276845/>.

BAKhtin, M. (1998): «Carnival and Carnivalesque» in Storey, J. (ed.) (1998): Cultural Theory and Popular Culture, Harlow, Pearson. 250-259.

DERRIDA, J. (2006): Specters of Marx, New York, Routledge.

Göncü, G. (ed.) (2013): «Yaşarken Yazılan Tarih», Ntv Tarih Dergisi, 54. $<$ http://www.yasarkenyazilantarih.com/>.

Johnson, B. (2005): «Istanbul's Vanished City of the Dead: The Grand Champs des Morts», The Fountain Magazine, 49: 41-47.

Nicolaus, M. (1993): Foreword to Grundrisse by K. Marx, London, Penguin. 7-64.

Scotт, J. (1990): Domination and the Arts of Resistance, London, Yale University Press.

Sözalan, Ö. (2013): «A Few Remarks on the Lessons of Gezi Uprising», The International Journal of Badiou Studies, 2 (1): 146-151.

VERSNEL, H. S. (1994): Inconsistencies in Greek and Roman Religion, Danvers, Brill \& Leiden.

Yilmaz, H. (2013): Becoming Turkish, New York, Syracuse University Press.

ZızeK, S. (2012): The Year of Dreaming Dangerously, New York, Verso. 


\section{Annex}

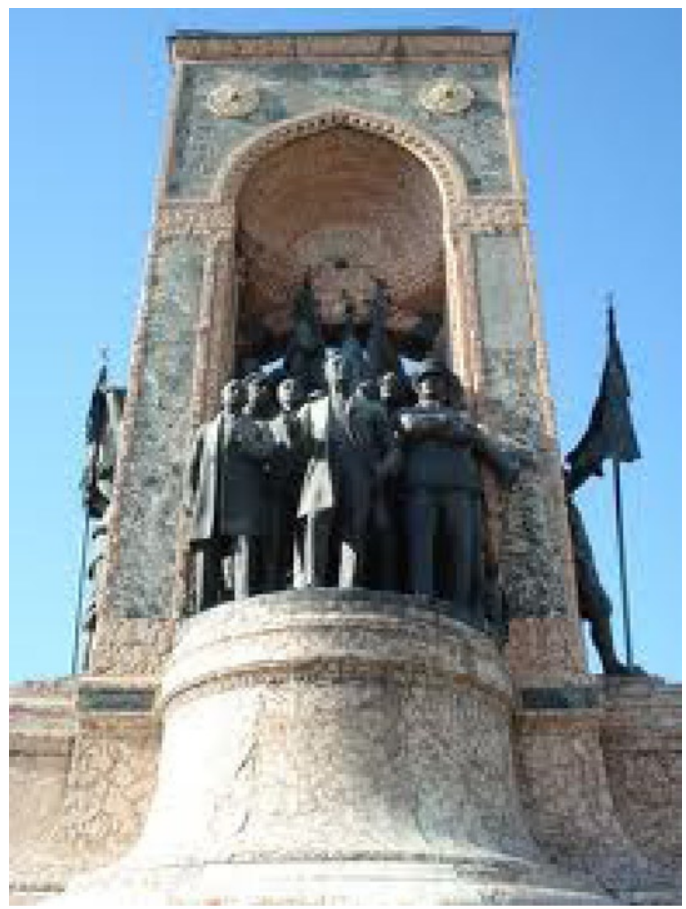

The South end of the Republic Monument facing İstiklal Street
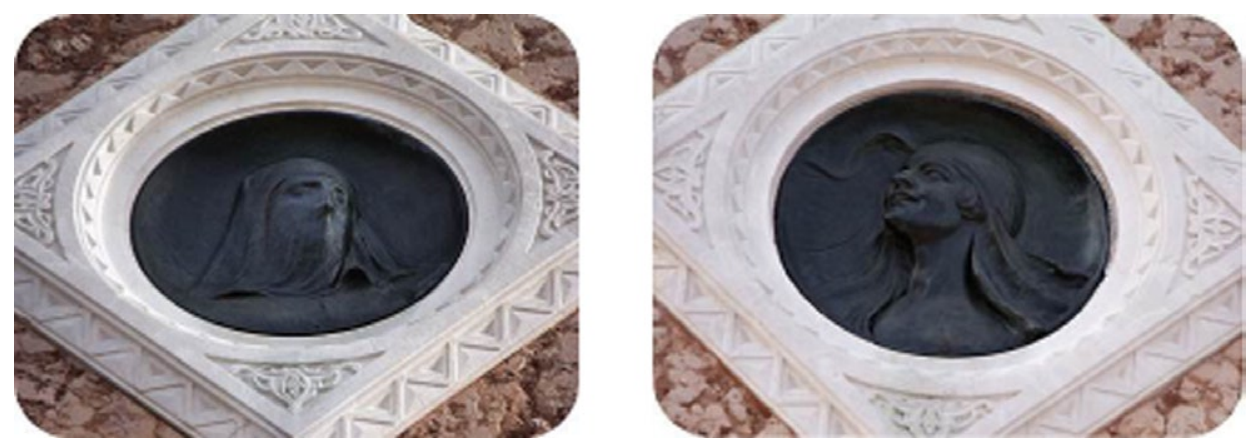

The veiled/unveiled women figures 


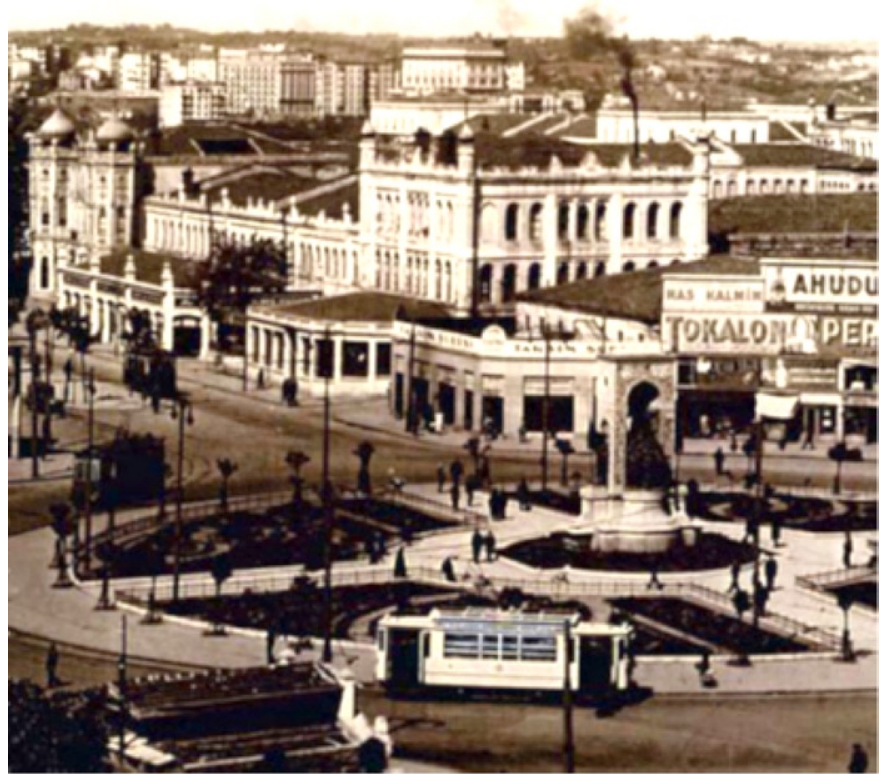

Late 1930s. The Republic Monument and Taksim Military Barracks
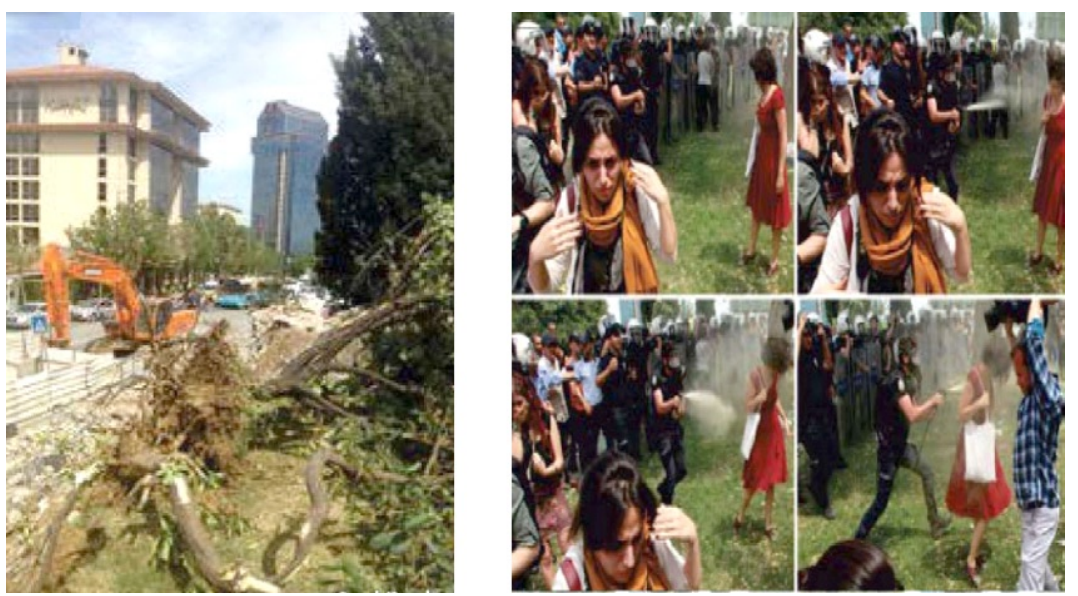

The uprooted trees in Gezi Park «The woman in red dress» 

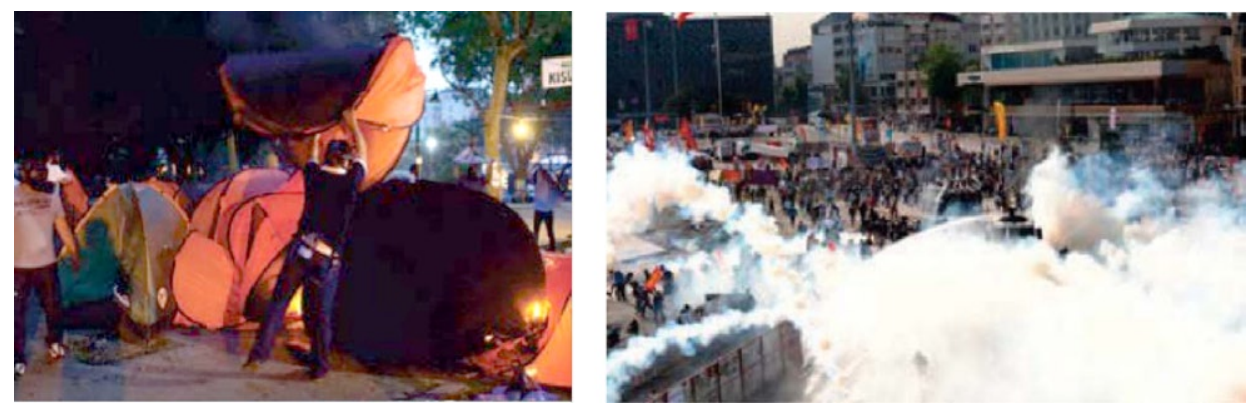

Burning the tents in Gezi and ensuing clashes in the square

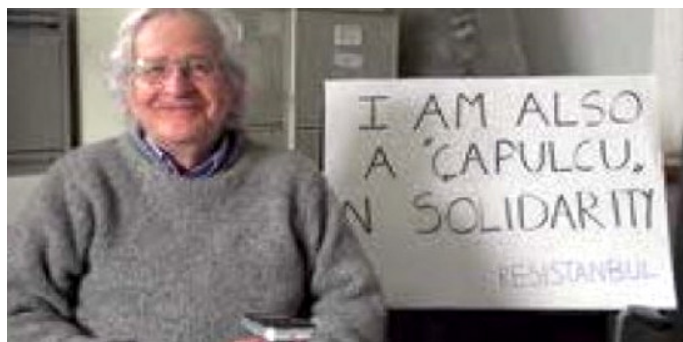

Chomsky in Solidarity 